\title{
Eco-Sustainable Metropolises: An Analysis of Budgetary Strategy in Italy's Largest Municipalities
}

\author{
Carla Del Gesso ${ }^{1}$ \\ ${ }^{1}$ Department of Economics, University of Molise, Campobasso, Italy \\ Correspondence: Carla Del Gesso, Department of Economics, University of Molise, Campobasso, Italy.
}

Received: January 21, 2020

Accepted: February 24, 2020

Online Published: March 5, 2020

doi:10.5430/ijba.v11n2p1

URL: https://doi.org/10.5430/ijba.v11n2p1

\begin{abstract}
The sustainable urban development agenda calls for city governments worldwide to integrate sustainability goals into their budgetary processes. This article presents the findings of an analysis of the integration of urban environmental sustainability into the budgetary strategy of fourteen Italian metropolitan municipalities. Its purpose is to find out the extent to which they are committed to the promotion of environmentally sustainable cities. A documentary research of both strategic planning documents and municipal budgets was conducted. Correlation and linear regression techniques were used for a quantitative data analysis which indicated a strong positive linear relationship between the amount of resources invested in environmental sustainability and the total availability of budgetary resources. Furthermore, the study found that all Italian metropolitan municipalities are integrating urban environmental sustainability objectives and supporting resources into their budgetary strategy but to a different extent and with a focus on waste. Further efforts are needed for an effective full integration, which is an enduring challenge for local government managers.
\end{abstract}

Keywords: sustainable urban development, urban environmental sustainability, strategic planning, budgetary resources, sustainable cities, metropolitan municipalities, Italian local governments

\section{Introduction}

\subsection{Rationale and Purpose}

Cities worldwide are becoming engaged in a more sustainable and inclusive growth. The United Nations 2030 Agenda recognizes the crucial role of cities in promoting sustainable development and has devoted a specific Sustainable Development Goal (SDG 11) to sustainable cities and communities (UN, 2015). Achieving sustainable urban development is becoming increasingly topical in an attempt to ensure more livable places for citizens, even more so in the context of megalopolises (Finco \& Nijkamp, 2001; Hutton, 2011; Loorbach \& Shiroyama, 2016). City governments are those primarily responsible for societal and ecological progress, since they serve as principle providers of services, housing, work, health, transport, infrastructure, economic activities, wealth, culture and much more. The transition to urban sustainability involves, therefore, a multiplicity of persistent challenges and sustainability issues, such as economic prosperity; safe and affordable housing; access to public services and spaces; eco-sustainable transport for all; social inclusion; and wellbeing. In addition, city governments must consider the safeguarding of natural resources, municipal waste collection, air emissions, urban pollution, soil use and other environmental concerns (Keivani, 2010; Loorbach \& Shiroyama, 2016). In other words, a city's commitment to sustainability means continuing to thrive and grow in an inclusive and safe way to ensure equal opportunities for all, without, however, damaging the territory and natural ecosystem but improving resource use and consumption (UN, 2015). However, as "The Sustainable Development Goals Report 2019" revealed, important performance gaps exist, indicating that substantial efforts are needed in order to achieve sustainable urbanization by 2030 (UN, 2019). Furthermore, the "2019 SDG Index and Dashboards Report for European Cities" (SDSN \& Telos, 2019) shows that major sustainable development challenges affect all 45 European capitals and large cities covered in the report, with the main gaps concerning environmental targets such as $\mathrm{CO}_{2}$ emission reduction. In particular, these challenges involve Southern European cities in Italy, Spain, Portugal, Greece, Malta and Cyprus, where cities ranked the worst when compared to the top performing Nordic cities (SDSN \& Telos, 2019).

These results call for policymakers to recognize urban sustainability gaps and implement consequent proactive local initiatives for policy improvement, especially in metropolises, in order to ensure more favorable living conditions for 
the large populations of these cities. Local governments are therefore called upon to integrate policy priorities for sustainable development into planning discourses, by establishing their own urban sustainability objectives in municipal budgetary strategy (Wheeler, 2004; Hutton, 2011).

The above scenario offers the motivation behind this study, which focuses on the environmental dimension of the sustainable urban development of metropolises. Accordingly, this article presents the findings of an analysis of the integration of urban environmental sustainability into the municipal budgetary strategy of fourteen large Italian cities that are viewed as metropolises. The main purpose of this analysis is to find out the extent to which these larger municipalities in Italy are committed to the promotion of environmentally sustainable cities in their planning practices. To accomplish this, a qualitative and quantitative data analysis of both the strategic planning documents and the municipal budgets was performed. Two research questions were addressed:

Research Question 1: What strategic objectives and related budgetary resources are being considered by Italian metropolitan municipalities in their planning for the eco-sustainable development of their urban contexts?

Research Question 2: What relationship exists between the budgetary resource availability of Italian metropolises and the spending allocations for the eco-sustainable development of their urban contexts?

This study provides answers to these questions. It seeks to offer both a theoretical and a practical contribution to sustainable urbanization discourses. Theoretically, this article highlights how a proper integration of policies concerning the sustainable urban development of the territory and the environment into municipal budgetary planning is essential for promoting more engagement with sustainability within metropolises. It also suggests ideas for future research avenues. Practically, this research may assist local government policymakers and managers to better define urban environmental sustainability policies and gaps, as well as discern priority goals and resources to be integrated into a municipality's budgetary planning.

The paper continues as follows. The ensuing subsection details the municipal budgetary planning documents analyzed by describing their configuration of missions and programs, which formally encourages the integration of urban environmental sustainability objectives into the budgetary strategy of Italian municipalities and the related information disclosures. Subsequently, an overview of the previous literature is provided. Section 2 defines the population under investigation and describes the methodology used to collect and analyze the data in order to address the research questions. The research findings are shown in Section 3 and then discussed in Section 4. Finally, the article concludes by highlighting the study implications and limitations with some practical recommendations for improving environmental sustainability planning in municipalities.

\subsection{Budgetary Planning in Municipalities in Italy}

The fundamental strategic planning tool used by Italian local governments is the "Documento Unico di Programmazione" (DUP), which discloses information about the territory, local policies and related resource allocations (Gori et al., 2018). This document was mandatorily introduced into Italian local governments in 2016, with decree no. 118/2011 on public accounting harmonization (and subsequent modifications and additions). It must be prepared by the municipal council in compliance with the provisions of the accounting principle applied to budgetary planning (referred to in attachment n. 4/1 of decree no. 118/2011). According to this applied accounting principle, the DUP is the instrument for strategic and operational guidance for local governments and it is the necessary prerequisite for all other planning documents such as the budget and the performance plan. Indeed, it sets out the strategic and operational objectives and action in the various policy areas (economic, social, environmental, etc.) in which the municipality plans to intervene during the reference period of three years. Therefore, spending and revenue allocations within the municipal budget derive from the DUPs, which inform the whole municipal budgetary cycle. More precisely, the DUP consists of two sections: the strategic section and the operational section. The first section defines the municipal strategic objectives - deriving from the political mandate guidelines and to be developed during the three-years - that the municipality assigns to the various missions of the budget. The second section identifies the operational objectives, or programs, for each mission of the budget that the municipality will need to fulfill in order to achieve the strategic objectives. Therefore, the municipal budget, which is a cash-based financial forecast document that authorizes expenditure and related funding resources, establishes a classification of expenses divided into missions (which represent the strategic objectives pursued) and programs (which show what the strategic objectives mean in operational terms). Consequently, each mission is divided into one or more programs. This division of the budget aims to ensure transparency for the process of public resource allocation and to increase awareness of spending goals (Mauro, 2019). Likewise, this budget structure is designed to ensure that financial resources are allocated to the different sectoral public policies such as those relating to social policies, work, safety, education, transport, economic development and policies for the environment. Indeed, the name of the programs 
reflects the main areas of intervention of the mission to which it refers, ensuring a representation of the budget that discloses what will be achieved by each municipality using public resources. The budget sets out the resources allocated for each mission for both the first year and the subsequent two years of the three-year reference period.

The budget structure of Italian municipal governments includes one particular mission devoted to the environment and named "Sustainable development and protection of the territory and the environment" (henceforth: Mission 9). This budgetary mission includes the following operational programs:

- Soil protection: which essentially concerns rational land use and the prevention and tackling of hydrogeological instability within the territory in order to avoid earthquakes, landslides, floods or other natural disasters;

- Environmental protection, enhancement and recovery: which generally refers to the safeguarding and conservation of the natural environment and its resources;

- Waste: which primarily involves the removal and management of the urban waste;

- Integrated water service: which concerns the rational, sustainable management of the supply of water as a primary citizen resource;

- Protected areas, natural parks, naturalistic protection and forestation: which mostly refers to the protection and safety of parks and green public areas of the city that can promote a better and inclusive livability;

- Protection and enhancement of water resources: which concerns the safeguarding of water resources that are part of the city's heritage;

- Air quality and pollution reduction: which essentially regards the reduction of pollutant gas emissions into the atmosphere that threaten air quality and encourage climate change and global warming.

These operational programs reflect the major areas of intervention through which each municipal government realizes, in concrete terms, its budgetary mission concerning the sustainable development and protection of the territory and the environment. Furthermore, these programs address both directly and indirectly, some specific targets of the global SDGs of the United Nations 2030 Agenda (UN, 2015). In particular, budgetary Mission 9, through its operational programs, touches upon some of the targets of SDG 11, such as those concerning the safeguarding of the world's natural heritage; the reduction in the number of deaths and people affected by disasters; the universal access to safe, inclusive, accessible, green public spaces; an attention to air quality; and waste management. Mission 9 also deals with universal and equitable access to safe and affordable drinking water, and more in general with the improvement of water resource management, which are targets set out in SDG 6, as well as with the reduction in the number of deaths and illnesses from air, water and soil pollution set out in SDG 3, and the improvement in energy efficiency included in SDG 7. In addition, Mission 9 involves SDG 13, which concerns combatting climate change and SDG 15 pertaining to the protection of terrestrial ecosystems, forests, and biodiversity and the prevention of land degradation (UN, 2015).

Consequently, an analysis of budgetary Mission 9 can provide an overview of how Italian metropolitan municipalities approach environmentally sustainable development issues. The Italian context may be therefore an interesting milieu to analyze the integration of urban environmental sustainability into the budgetary planning of metropolitan municipalities. In particular, a combined analysis of the municipal planning documents relating to the DUPs and budgets allows this study to understand what strategic goals and resources are being considered by Italian metropolises in their planning for the eco-sustainable development of their urban contexts (1st $R Q$ ) and what relationship exists with budgetary resource availability (2nd $R Q)$.

\subsection{An Overview of the Related Literature}

Over the last two decades, metropolitan areas around the world have undertaken innovation initiatives promoting economic, environmental, and social development in response to the challenges of urban sustainability (Joss, 2011; Bibri \& Krogstie, 2017). These initiatives have resulted in a multiplicity of new conceptual labels for cities, such as "sustainable cities", "eco-cities", and "green cities", which are among the most common labels, and with "low carbon cities" and "smart cities" being those used most recently (De Jong et al., 2015; Pevcin, 2019). Given the vulnerability, uncertainty and complexity of future urban development, most city innovations include, or relate to, the three main pillars of the sustainability concept (i.e. economic, environmental and social) (Williams K., 2010; Elmqvist et al., 2019). Sustainability, therefore, is increasingly a topical issue both in urban policymaking and academic discourse, where it has "become an all-inclusive paradigm" (Campbell, 2016, p. 388). Indeed, within the urban context, sustainability issues reflect the concept of sustainable urban development, which is seen as the improvement of the quality of life within cities and includes multiple dimensions, such as ecological, cultural, 
political, institutional, social and economic (Yigitcanlar \& Dizdaroglu, 2014).

The concept of sustainable urban development is highly topical but not new; it has been used for a long time in relation to the perpetual need worldwide for cities to adopt environmentally sustainable behavior in their rapid and dynamic urbanization (Finco \& Nijkamp, 2001; Yigitcanlar \& Teriman, 2015). Cities, particularly the larger ones, are considered to be a main source of the environmental crisis and a major cause for concern. Due to the concentration of people and activities, cities are the largest contributors to greenhouse gas emissions, major consumers of energy and environmental resources, and the highest producers of waste (Bulkeley \& Betsill, 2005; Keivani, 2010; Bibri \& Krogstie, 2017). Indeed, the theoretical debate agrees in envisioning sustainable urban development (and hence, sustainability) as the main means by which to protect territories and the environment from the negative ecological externalities of urban industrialization and economic growth, the rapid expansion of urban population density, and the (unsustainable) consumption and depletion of scarce natural resources (Burton et al., 2004; Yigitcanlar \& Teriman, 2015). More precisely, there is an overall consensus in the current urban sustainability debate that cities have a leading responsibility to developing remedies and solutions to global environmental problems in order to build a sustainable future for the planet (Angelo \& Wachsmuth, 2019). A strong relationship between environmental sustainability and the development of urban competitiveness has been emphasized (Hu, 2015).

Therefore, the central role that local governments can play in adopting sustainability initiatives appears to be widely recognized within the literature (Saha, 2009; Nogueiro \& Ramos, 2014). This view has also been endorsed by the studies addressing local government sustainability reporting. For instance, the recent study by Niemann and Hoppe (2018) shows how - while sustainability reporting practices in the public sector are still in their infancy under the influential international framework of the Global Reporting Initiative - city government engagement in reporting sustainability performance is rising. Likewise, the study by Williams and colleagues found that a reasonable amount of Australian local governments had implemented sustainability reporting (Williams B. et al., 2011), although the subsequent study by Hossain (2018) in the same context revealed that the practice was still not widespread. Hence, as Nogueiro and Ramos $(2014$, p. 21) have noted, local governments appear to be aware of the need for an organizational change regarding sustainability. They are also mindful of the need to integrate environmental and sustainability initiatives and tools into their activities in order to improve their own performance and inform stakeholders.

Notwithstanding the fact that local sustainability initiatives are on the rise, the literature highlights the fact that sustainable urban development has not been achieved and persists as a challenge for local government managers on a global scale (e.g., Yigitcanlar \& Teriman, 2015; Hermelin \& Andersson, 2018; Zeemering, 2018). In this regard, Zeemering (2018) emphasizes how a management focus on the integration of sustainability into strategic planning processes is required in order to advance sustainability in local governments. In fact, many of the studies that have addressed sustainability in the urban context have discussed the great potential for planning to support the transition toward achieving the sustainable urban development agendas of cities, which include urban environmental sustainability (e.g., Wheeler, 2004; Saha \& Paterson, 2008; Mazzara et al., 2010; Davidson \& Arman, 2014; Yigitcanlar \& Dizdaroglu, 2014; Loorbach et al., 2016).

Proper organizational planning has become essential for the successful implementation of sustainable development within organizations (Filho et al., 2019). As Mazzara, Sangiorgi and Siboni argued (2010), strategic planning plays a key role in public sector organizations by supporting policymakers in their decision processes: by defining valuable public policies aligned to the mission; by addressing territorial issues and community needs; and by explaining how and with the allocation of what resources sustainability initiatives can be implemented. Therefore, the integration of sustainable development policies into planning, decision-making and financial resource allocation processes provides evidence of the organizational commitment to achieving sustainable development performance and positive externalities (Bebbington, 2007).

Furthermore, as recently highlighted by Hossain (2018), the integration of sustainable development in strategic planning is a key propelling force to foster government sustainability reporting practice. Moreover, sustainability reporting practice can benefit the organizational change toward sustainability and encourage sustainability policies (Niemann et al., 2016). This is very important as stakeholder demand for transparent sustainability disclosures has increased (Galera et al., 2014; Hossain, 2018).

However, as a recent study that investigated the Portuguese context demonstrates, the adoption level of sustainability policies in public sector organizations is still low (Figueira et al., 2018). Likewise, the study by Nogueiro and Ramos (2014), that evaluated environmental engagement in Portuguese municipalities, found a low level of integration of 
environmental policies in planning. In addition, Hermelin and Andersson (2018) studied the integration of sustainable development policies for green growth in municipal policy in Swedish cities and found it to be weak. Several concerns about the incorporation of sustainability goals in local government planning practices also emerged from the study by Saha and Paterson (2008) that investigated the empirical context of all medium to large cities (with a population over 75,000) in the United States. This study revealed that few cities integrated sustainability into their long-term strategic plan with a strong government commitment; water-quality protection and curbside recycling were the most frequently adopted sustainability initiatives within large US municipalities in relation to environmental protection. A lack of adequate funding was indicated as a principal impediment to more effective environmental protection implementation. In effect, as Sandu and Bănică (2015) reported in their study, the allocation of environmental expenditure is a central factor for achieving sustainable development, as investments sustain environmental protection and show the saliency given by city governments. As noted by Wilkinson and colleagues, budgets, which are essential for realizing all government functions, are crucial for the integration of environmental policy: budgeting has a potential role in this "because public spending, and the process of rising the revenue to support it, can have a wide range of environmental impacts, both beneficial and damaging" (Wilkinson et al., 2008, p. 70).

Regarding local governments in Italy, which provide the empirical context for the present study, research by Mazzara and colleagues (2010) showed how sustainable development policies began to be integrated into the strategic plans of a group of provinces and municipalities. In addition, the recent study by Vagnoni and Moradi (2018), which evaluated the transition efforts of Italian municipalities toward low carbon urban mobility, highlights how municipal strategies and plans have a direct effect on goal achievement and that strategies are influenced by the availability of financial resources. To the best of the author's knowledge, no study has so far systematically analyzed the plans and budgets of Italian metropolitan municipalities to examine their engagement with urban environmental sustainability integration within their budgetary strategy.

The urban sustainability literature this section has sought to provide a brief glimpse of includes a strong interdisciplinary scientific debate about the environmentally sustainable development of cities. This research seeks to add new insight to this debate, not merely by emphasizing the need of metropolises to strategize environmental sustainability - through the integration of priorities, objectives and supportive investments into their municipal budgetary strategy - but also by ascertaining the existence of a relationship between these investments and the municipal's financial resource availability.

\section{Data Collection and Analysis Methodology}

\subsection{Population Selection}

In order to answer the two research questions outlined in the Introduction, the entire target population of Italian metropolitan municipalities was investigated. This population consists of 14 larger Italian cities that were selected based on both the number of inhabitants (according to the Italian National Statistics Institute data updated on 1.1.2019) and law no. 56/2014 on metropolitan cities. This law established ten "metropolitan cities", and four more were added at a later date. In 2015 these metropolitan cities replaced the pre-existing provinces of the same name as second level local governments. Therefore, the cities investigated by this study into the municipal level of government are the chief-towns of these 14 ex-provinces now labelled "metropolitan cities". The following large cities, here listed in descending order of inhabitant number, were identified as metropolises in Italy: Rome; Milan; Naples; Turin; Palermo; Genoa; Bologna; Florence; Bari; Catania; Venice; Messina; Reggio Calabria; and Cagliari. It is to be emphasized, however, that in Italy there are few cities that can be correctly termed metropolises. Indeed, there are a total of 45 large municipalities with a population of over 100,000 inhabitants but only Rome $(2,872,800$ inh.), Milan (1,366,180 inh.), Naples (966,144 inh.) and Turin (882,523 inh.) have populations that exceed or are close to one million. However, the decision was made to select the aforementioned 14 cities because each is located within a wider metropolitan area which includes the city and its hinterland; thus, each selected city is the core and largest municipality of a particular metropolitan area.

\subsection{Data Collection Methodology}

Once the population to be analyzed was defined, empirical data were gathered from both the municipal DUPs and budgets for the three-year period 2019-21, which constitute the source materials for this study. Both DUPs and budgets were retrieved from the cities' official websites where they are publicly available under the "transparency administration" section. However, for one city (Catania) the DUP and budget for 2019-21 were not available on its website and consequently, the most recent documents were analyzed, which related to the period 2018-20. 
An accurate review of these official documents was needed to collect qualitative and quantitative raw data to be processed and interpreted subsequently (Finnegan, 1996; Johnson \& Turner, 2003, p. 314; Bowen, 2009). The documentary research method was therefore used as a data collection method. This method concerns the study of documents containing information about the phenomenon to be investigated; it can be a key approach in social research (Mogalakwe, 2006; Chohan, 2019). Notably, this approach appeared to be suitable for an analysis of the integration of urban environmental sustainability into the budgetary strategy of Italian metropolitan municipalities. A proper database consistent with the purposes of this study was therefore devised. Indeed, data included the following information obtained from the DUPs and budget documents: the strategic objectives that each of the 14 cities assigned to Mission 9 for the eco-sustainable development of its urban context; the total spending allocations from the budget for Mission 9; the total spending allocations for each individual operational program relating to this mission (namely: soil protection; environmental protection, enhancement and recovery; waste; integrated water service; protected areas, natural parks, naturalistic protection and forestation; protection and enhancement of water resources; and air quality and pollution reduction); and the balanced total of all budget revenues and expenditure.

\subsection{Data Analysis Methodology}

Data analysis was then carried out using Microsoft Excel software in order to answer the research questions posed by this study. In particular, the above qualitative and quantitative information obtained from the documentary review of the DUPs and budgets was arranged consistently to determine what strategic objectives and related budgetary resources are being considered by Italian metropolitan municipalities in their planning for the eco-sustainable development of their urban contexts (1st $R Q$ ).

Furthermore, in order to determine what relationship exists between the budgetary resource availability and the spending allocations (relating to Mission 9) for the eco-sustainable urban development of Italian metropolises (2nd $R Q$ ), a quantitative analysis of the budget data for the first financial year 2019 was performed using correlation and linear regression techniques. These are the most common statistical methods applied for investigating the linear association between two continuous variables (Bewick et al., 2003; Zou et al., 2003). In particular, the correlation, which is measured through the calculation of an index such as Pearson's correlation coefficient (PCC), quantifies and interprets the strength of a linear relationship between two variables, whereas linear regression expresses this relationship in the form of a straight line equation (Bewick et al., 2003; Zou et al., 2003; Schober et al., 2018). Indeed, the PCC (or Pearson product-moment correlation coefficient) is a bi-variate statistical measure of the covariance of two variables (how they vary together), which therefore expresses how strongly these variables are related to each other. Normally indicated as " $r$ ", the PCC ranges from -1 and +1 and is interpreted as follows (Schober et al., 2018):

- a positive value of $r$ between 0 and +1 indicates that a positive linear relationship (or direct relationship) exists between the two variables (i.e., if one variable increases, the other variable also increases);

- a negative value of $r$ between -1 and 0 indicates that a negative linear relationship (or indirect relationship) exists between the two variables (i.e., if one variable increases, the other variable decreases);

- a value of $r=0$ indicates that no linear relationship exists between the two variables (i.e., the two variables are not related).

Consequently, the relationship becomes stronger (that is, the dispersion decreases) as the absolute value of $r$ increases and approaches a straight line (in a scatter diagram) as the coefficient approaches the value -1 or +1 . In contrast, the more the value of $r$ approaches 0 the weaker the relationship, i.e. the dispersion of the points on the scatter diagram increases; thus, the relationship cannot be suitably described by a linear equation (Bewick et al., 2003; Schober et al., 2018, p. 1764).

The data values were therefore represented graphically in a scatter diagram and the PCC was calculated in order to determine the presence of a linear relationship and to measure the strength of such a relationship between the "budgetary resource availability" (variable $x$ ) and the "spending allocations for eco-sustainable urban development" (variable $y$ ). In other words, the PCC was used to determine whether the availability of financial resources had any bearing on the investments made in environmental sustainability, i.e. how these investments vary with more resources. More precisely, the correlation aimed to ascertain whether:

- as the "budgetary resource availability" increases, the "spending allocations for eco-sustainable urban development" also increase - if there is a positive linear relationship between these two variables $(r>0)$;

- as the "budgetary resource availability" increases, the "spending allocations for eco-sustainable urban development" decrease - if there is a negative linear relationship between these two variables $(r<0)$; 
- as the "budgetary resource availability" increases, the "spending allocations for eco-sustainable urban development" remain unchanged - if there is no linear relationship between these two variables $(r=0)$.

The PCC was computed for the two sets of values collected from the budget data for the year 2019 of the 14 Italian metropolitan municipalities (the budgetary resource availability - i.e. the total budget revenue - and the spending allocations for Mission 9 respectively), by using the "Correl" Excel function (Zou et al., 2003). Subsequently, the coefficient of determination $\left(\mathrm{R}^{2}\right)$, which is given by the square of the PCC, was also calculated in order to determine the proportion of variance in the "spending allocations for eco-sustainable urban development" (dependent variable) that is accounted for by the "budgetary resource availability" (independent variable) (Schober et al., 2018). Thus, the value of $\mathrm{R}^{2}$, which ranges between 0 and 1 , indicates the extent to which the variable "spending allocations for eco-sustainable urban development" is predictable.

Finally, a simple linear regression analysis was conducted in order to find the equation of the straight line that establishes the relationship between the budgetary resource availability and the spending allocations for eco-sustainable urban development. This (regression) equation is mathematically expressed as

$$
\mathrm{y}=\mathrm{a}+\mathrm{bx}
$$

where: $y$ is the dependent variable "spending allocations for eco-sustainable urban development"; $x$ is the independent variable "budgetary resource availability"; parameter $a$ is the intercept (on the y axis); and parameter $b$ is the slope of the regression line (Zou et al., 2003). Indeed, simple linear regression best fits a line through the data points of the scatter diagram (in which each pair of $x-y$ values are represented); such a line allows the values assumed by $y$ based on the fixed or known values of $x$ to be predicted or estimated (Kutner et al., 2005). The intercept and slope parameters that determine this regression line were calculated using the method of least squares (Zou et al., 2003). Hence, the slope parameter $b$ of the straight line was first calculated as:

$$
\frac{\operatorname{cov}(x, y)}{\sigma^{2} x}
$$

and later the intercept parameter $a$ was obtained as:

$$
\overline{\mathrm{y}}-\mathrm{b} \overline{\mathrm{x}}
$$

In summary, while correlation was used to describe the direction and strength of the relationship being investigated, simple linear regression was used to establish a dependency in this relationship, which is expressed in the form of a linear equation that enables an evaluation of the relative impact of the predictor variable $x$ "budgetary resource availability" on the outcome variable $y$ "spending allocations for eco-sustainable urban development" (Zou et al., 2003; Schober et al., 2018)

\section{Research Findings}

This section describes the results of the study in response to the two research questions.

\subsection{Results for the 1 st $R Q$}

The strategic objectives and the related financial resources of the 14 Italian metropolitan municipalities assigned to budgetary Mission 9 were analyzed in response to the 1 st $R Q$. An overview of the urban environmental sustainability goals and resources that characterize the budgetary planning practices of these larger municipalities is provided in Table 1, where cities are listed in descending order of the inhabitant number.

\begin{tabular}{|c|c|c|c|c|c|}
\hline \multirow{4}{*}{ Cities } & \multirow{4}{*}{ Strategic objectives assigned to Mission 9} & \multicolumn{4}{|c|}{ Financial resources assigned to Mission 9} \\
\hline & & & $\mathbf{A}$ & B & $\mathbf{A} / \mathbf{B}$ \\
\hline & & & $\begin{array}{l}\text { Spending } \\
\text { allocations for } \\
\text { Mission } 9(€)\end{array}$ & $\begin{array}{l}\text { Total budget } \\
\text { revenues and } \\
\text { expenditure }\end{array}$ & $(\%)$ \\
\hline & & & & $(€)$ & \\
\hline Rome & $\begin{array}{l}\text { Protect the territory by preventing hydrogeological instability; } \\
\text { rationalize energy consumption; tackle animal abuse and protect }\end{array}$ & 2019 & $927,579,840$ & $11,275,715,555$ & 8.23 \\
\hline
\end{tabular}

Table 1. The strategic objectives and financial resources Italian metropolitan municipalities assign to budgetary Mission 9 for "Sustainable development and protection of the territory and the environment" 
biodiversity; manage green assets; regulate and monitor polluting emissions; develop environmental education courses to raise awareness about environmental sustainability issues; increase and improve separate waste collection and reduce the production of unsorted waste.

\begin{tabular}{llll}
2020 & $903,678,978$ & $5,556,983,949$ & 16.26 \\
\hline 2021 & $887,686,045$ & $5,248,510,990$ & 16.91 \\
\hline 2019 & $629,865,174$ & $8,050,666,877$ & 7.82 \\
\hline 2020 & $712,958,090$ & $7,872,685,516$ & 9.06 \\
\hline 2021 & $477,492,419$ & $6,847,739,657$ & 6.97 \\
\hline & & & \\
\hline & & $7,641,972,754$ & 4.50 \\
\hline & & & \\
\hline & & & \\
\hline
\end{tabular}

Support the various city ecosystems; protect the territory from the risk of landslides and hydrogeological instability; implement the sustainable energy action plan; strengthen interventions to protect the city's fauna; implement the plans for a smart city; enhance and take care of urban Naples green areas; protect the sea and enhance the city coastline; promote a culture of environmental sustainability in order to make an integrated waste cycle, energy saving and respect for the environment priorities for collective action; efficient management of the integrated water cycle; promote the spread of renewable energy sources, especially solar.

Prevent and combat hydrogeological instability; stop the depletion of soil and subsoil and protect the environment; improve environmental connectivity and enhance urban ecological networks; promote environmental sustainability through education; raise awareness of citizens about the conscious use of natural resources; promote respect for animals; improve the management of the waste cycle and introduce the zero waste principle with incentives for good practice; establish entirely public and participatory water management; create an integrated green city system which can be used by children and adults and which helps improve everyone's quality of life; improve safety in parks and redevelop play areas; reduce air pollution; reduce the waste of natural resources and the inefficiencies that generate pollution.

\begin{tabular}{llll}
2019 & $227,558,934$ & $3,929,270,126$ & 5.79 \\
2020 & $218,510,649$ & $3,561,749,543$ & 6.13 \\
\hline & & & \\
\hline & & & \\
\hline 2021 & $217,078,159$ & $3,657,351,921$ & 5.94
\end{tabular}

Consolidate sensitivity to environmental issues and community involvement; provide the city with efficient cleaning services, by

Palermo relaunching separate waste collection; create new green spaces for children, the young and the elderly; make the city greener by creating spaces for socializing and livability.

\begin{tabular}{llll}
\hline 2019 & $175,517,622$ & $2,281,283,329$ & 7.69 \\
\hline 2020 & $149,841,679$ & $2,222,543,144$ & 6.74 \\
\hline 2021 & $143,505,342$ & $2,104,981,706$ & 6.82 \\
\hline
\end{tabular}

Reduce the hydrogeological risk in the territory by carrying out planned works and intervening with preventive actions; create a model of sustainable development integrated with economic development for a Genoa healthy and clean city, where the green heritage and parks are seen as a common good; realize a clean and orderly city where there is no waste but material and energy to be collected and transformed in a safe way for citizens and the environment.

\begin{tabular}{llll}
\hline 2019 & $220,383,179$ & $1,487,463,578$ & 14.82 \\
\hline 2020 & $202,055,844$ & $1,346,441,717$ & 15.01 \\
\hline 2021 & $186,785,396$ & $1,296,344,242$ & 14.41
\end{tabular}

\begin{tabular}{|c|c|c|c|c|c|}
\hline \multirow{3}{*}{ Bologna } & \multirow{3}{*}{$\begin{array}{l}\text { Green and urban environment care; environmental protection and } \\
\text { recovery for sustainable development of the territory. }\end{array}$} & 2019 & $107,408,167$ & $993,800,000$ & 10.81 \\
\hline & & 2020 & $97,434,144$ & $953,000,000$ & 10.22 \\
\hline & & 2021 & $89,590,714$ & $884,600,000$ & 10.13 \\
\hline \multirow{3}{*}{ Florence } & \multirow{3}{*}{$\begin{array}{l}\text { Create an environment for a green city; complete the work on the } \\
\text { "Parco delle Cascine". }\end{array}$} & 2019 & $118,106,492$ & $2,990,292,838$ & 3.95 \\
\hline & & 2020 & $105,371,265$ & $2,798,875,603$ & 3.76 \\
\hline & & 2021 & $103,533,395$ & $2,647,928,570$ & 3.91 \\
\hline
\end{tabular}




\begin{tabular}{|c|c|c|c|c|c|}
\hline \multirow{3}{*}{ Bari } & \multirow{3}{*}{$\begin{array}{l}\text { Protect ecological systems; create three new large urban parks and } \\
\text { enhance green areas in order to increase green areas per capita by } 40 \text {; } \\
\text { monitor and optimize energy flows, avoiding wastages; reduce } \mathrm{CO}_{2} \\
\text { emissions by } 40 \text {; differentiate waste more and in a better way and } \\
\text { reduce waste production; educate about the environment; reduce } \\
\text { hydrogeological risk. }\end{array}$} & 2019 & $96,270,572$ & $797,643,258.33$ & 12.07 \\
\hline & & 2020 & $121,005,664$ & $765,155,015$ & 15.81 \\
\hline & & 2021 & $104,495,421$ & $645,364,462$ & 16.19 \\
\hline \multirow{3}{*}{ Catania $^{*}$} & \multirow{3}{*}{$\begin{array}{l}\text { Prevent seismic risk; put the suburbs at the center of policymaking; } \\
\text { protect the city's green spaces; enhance and renovate green spaces and } \\
\text { street furniture; promote separate waste collection; strengthen public } \\
\text { fountains and the use of alternative and clean energies; strengthen } \\
\text { integrated projects for the reduction of } \mathrm{CO}_{2} \text { emissions. }\end{array}$} & 2019 & $168,652,417$ & $1,475,839,824$ & 11.43 \\
\hline & & 2020 & $495,442,633$ & $1,713,624,698$ & 28.91 \\
\hline & & 2021 & NA & NA & - \\
\hline \multirow{3}{*}{ Venice } & \multirow{3}{*}{$\begin{array}{l}\text { Improve the livability of the city for all citizens; ensure the highest } \\
\text { quality of the natural environment and landscape; fight pollution, fight } \\
\text { against wave motion and reorganization of water traffic; protect } \\
\text { animals; improve the collection, treatment and disposal of municipal } \\
\text { waste. }\end{array}$} & 2019 & $205,180,548$ & $1,977,799,324$ & 10.37 \\
\hline & & 2020 & $130,374,481$ & $1,713,824,722$ & 7.61 \\
\hline & & 2021 & $135,958,699$ & $1,703,465,837$ & 7.98 \\
\hline \multirow{3}{*}{ Messina } & \multirow{3}{*}{$\begin{array}{l}\text { Coordinate of environmental hygiene services and management of } \\
\text { services relating to animal welfare and city hygiene. }\end{array}$} & 2019 & $84,064,637$ & $739,928,264$ & 11.36 \\
\hline & & 2020 & $71,508,624$ & $702,375,548$ & 10.18 \\
\hline & & 2021 & $53,667,590$ & $633,787,527$ & 8.47 \\
\hline \multirow{3}{*}{$\begin{array}{l}\text { Reggio } \\
\text { Calabria }\end{array}$} & \multirow{3}{*}{$\begin{array}{l}\text { Protect and enhance public green spaces; systematize administrative } \\
\text { procedures for the protection of public green spaces; encourage separate } \\
\text { waste collection; implement safety levels with reference to } \\
\text { hydrogeological risk. }\end{array}$} & 2019 & $112,190,729$ & $714,577,074$ & 15.70 \\
\hline & & 2020 & $63,472,140$ & $409,653,542$ & 15.49 \\
\hline & & 2021 & $60,100,558$ & $374,780,383$ & 16.04 \\
\hline \multirow{3}{*}{ Cagliari } & \multirow{3}{*}{$\begin{array}{l}\text { Mitigate the hydrogeological risks to the city; rationalize water } \\
\text { resources; design and manage one million square meters of greenery; } \\
\text { raise awareness of green culture; transform the municipal solid waste } \\
\text { collection service; prevent pollution; draw up noise reduction plans. }\end{array}$} & 2019 & $93,432,846$ & $500,212,033$ & 18.68 \\
\hline & & 2020 & $71,165,372$ & $404,256,655$ & 17.60 \\
\hline & & 2021 & $53,301,779$ & $307,908,602$ & 17.31 \\
\hline
\end{tabular}

Source. Elaboration from the documentary review of municipal DUPs and budgets 2019-21; ${ }^{*}$ Data obtained from the DUP and budget for 2018-20 as the documents for 2019-21 were not available.

Table 1 shows how all the 14 metropolitan municipalities are integrating urban environmental sustainability objectives into their budgetary strategy and supporting them with financial resource allocations. Different levels of engagement with the promotion of environmentally sustainable cities can be seen. Indeed, the percentage of spending allocations for Mission 9 when compared to the total budget expenditure (which coincides with the total of budget revenues or budgetary resource availability) is quite variable. This percentage is minimal and remains around $4 \%$ in two cases (Naples and Florence), while in some cases it reaches or even exceeds $15 \%$ over the three years. A positive note is that the proportion of spending allocations for Mission 9 shows an increase during the three years in several cases, even in the presence of a reduction of overall budget revenues (Table 1). Therefore, the sustainable development and protection of the territory and the environment appears to be seen as a priority issue for the decision-making process of Italian metropolitan municipalities.

However, strategic attention is almost exclusively focused on the separate collection of waste and the care of urban green areas. This is better evident in Table 2, which shows how the percentage of spending allocations for Mission 9 is spread across the various programs of the mission. Indeed, these spending allocations tend to converge on the "Waste" program, which is where each city allocates most of its resources. Each city also allocates financial resources to the "Environmental protection, enhancement and recovery" program, although these resources are significantly less than those allocated to the "Waste" program. Concerning the remaining programs, not all cities allocate resources to all of them. Notably, some programs do not report expenditure allocations despite the fact that specific strategic objectives of Mission 9 explicitly concern them. For instance, Rome and Bari include both the prevention of hydrogeological risk and the reduction of polluting emissions among the goals of Mission 9 but they do not assign resources to the respective "Soil protection" and "Air quality and pollution reduction" programs. 
Indeed, in all 14 cities, very scarce resources are allocated to the latter program, where spending is just above $0 \%$. Likewise, limited resources are assigned to the "Integrated water service" program with a few exceptions. In addition, allocations for the programs "Protection and enhancement of water resources" (which only concerns Milan and Bologna) and "Protected areas, natural parks, naturalistic protection and forestation" are also almost nil (Table 2).

Table 2. Percentage spending allocations of Italian metropolitan municipalities for each program of their budgetary Mission 9 "Sustainable development and protection of the territory and the environment"

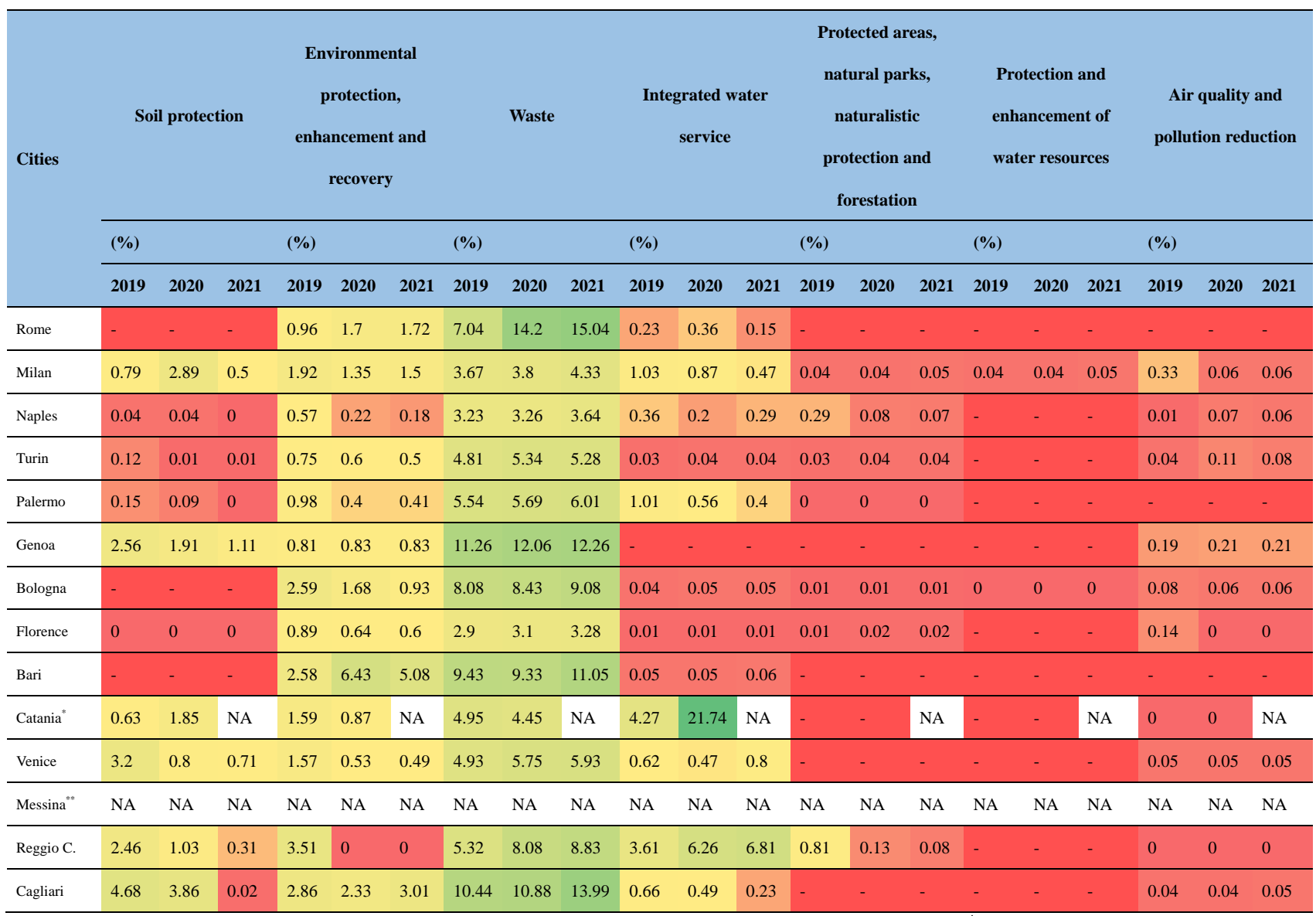

Source. Data processing from the documentary review of municipal budgets 2019-21; ${ }^{*}$ Data obtained from the DUP and budget for 2018-20 as the documents for 2019-21 were not available; ${ }^{* *}$ The municipal budget document does not report the details of the spending allocations for the individual programs of Mission 9.

\subsection{Results for the 2 nd $R Q$}

The relationship between the budgetary resource availability (i.e. the total budget revenues) and the spending allocations for eco-sustainable development (i.e. the spending allocations for Mission 9) of the 14 Italian metropolitan municipalities was studied in order to answer the $2 n d R Q$. The scatter diagram in Figure 1 reveals a high degree of association between these two variables. Indeed, the point cloud data are closely grouped, and a straight line can be drawn through them showing how the two variables are linearly related to each other. The presence of a strong positive correlation between the budgetary resource availability and the spending allocations for eco-sustainable development is also demonstrated by the high positive value of the PCC $(r=0.936)$ which approaches +1 (Zou et al., 2003; Schober et al., 2018). Incidentally, $r$ was also calculated for the years 2020 and 2021 and showed values of 0.716 and 0.952 respectively. Therefore, the PCC establishes the existence of an intelligible, strong positive linear relationship, or direct relationship. This means that investments for urban environmental sustainability are highly affected by the availability of financial resources and tend to increase as resources increase (Figure 1). 


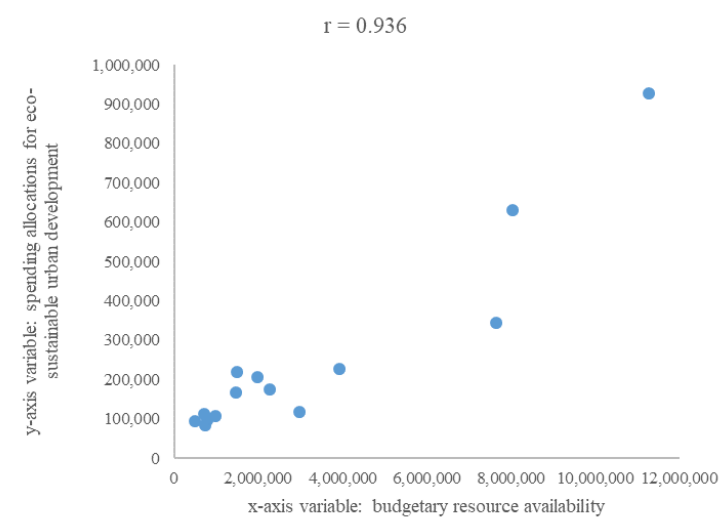

Figure 1. Scatter diagram with Pearson's correlation coefficient

Source. Own construction from the budget data values (expressed in thousands of euro) for the first financial year 2019.

This reasoning is also confirmed by the coefficient of determination $\left(\mathrm{R}^{2}\right)$, whose value was found to be 0.877 . Indeed, it indicates that almost $88 \%$ of the variability in the "spending allocations for eco-sustainable urban development" (dependent variable $y$ ) is explained by the "budgetary resource availability" (independent variable $x$ ), although neither $r$ nor $\mathrm{R}^{2}$ are able to demonstrate a causal relationship between these variables.

The results of both coefficients (the PCC and the coefficient of determination) clearly indicate that the relationship between the budgetary resource availability and the spending allocations for eco-sustainable development within the 14 Italian metropolises can be suitably described by a linear equation (Figure 2). Simple linear regression was therefore an appropriate model for representing the data. Figure 2 shows that the regression line that best fits the cloud of data points in the scatter diagram is expressed by the equation $y=35289+0.0672 x$, where the value 35289 (i.e. parameter $a$ ) indicates the intercept of this line, whereas the value 0.0672 (i.e. parameter $b$ ) indicates its slope.

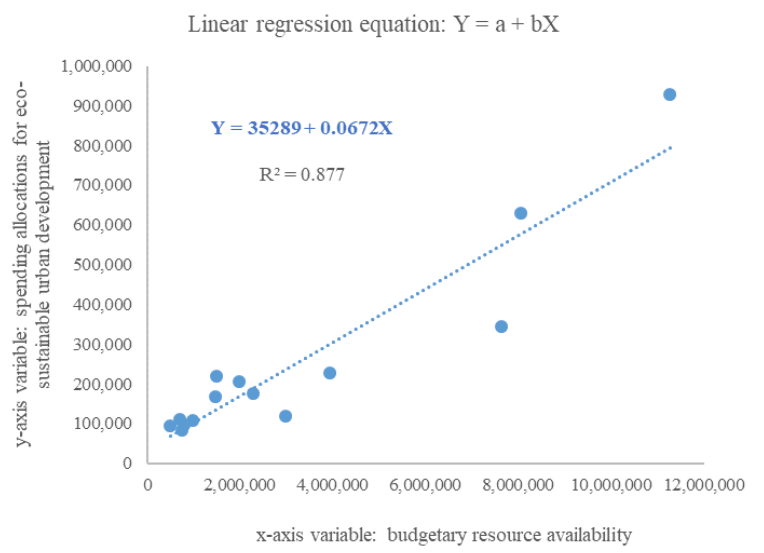

Figure 2. Graphical representation of the regression line that has equation $y=35289+0.0672 x$

Source. Own construction from the budget data values (expressed in thousands of euro) for the first financial year 2019.

The equation of the regression line thus determined may be used to provide predicted values for the $(y)$ investments in urban environmental sustainability for any given value of the $(x)$ budgetary resource availability. For instance, if in the future, a metropolitan municipality has additional availability in its budget revenues of one million euro (i.e., $\mathrm{x}=1000$ expressed in thousands of euro), it is possible to estimate that there will be a potential increase in the expenditure allocations for the environment to approximately $y=35289+0.0672 * 1000=35356.2$ euro. This 
and other predictions can be useful for metropolitan municipalities carrying out their budgetary planning, that need to strategize the environmental dimension of their sustainable urban development.

\section{Discussion}

This study has examined the integration of the environmental dimension of sustainable urban development into the budgetary strategy of Italian metropolitan municipalities. A documentary research of DUPs and budgets allowed it to establish the extent to which these metropolitan municipalities are committed to the promotion of environmentally sustainable cities in their budgetary planning practices. In doing so, two research questions were addressed which have been answered in the previous section.

The results for the $1 s t R Q$ showed that, although to a different extent, all the metropolitan municipalities studied are engaged with the promotion of eco-sustainability by integrating their own urban environmental sustainability goals and resources into their budgetary strategy. Indeed, each municipality set out one or more strategic objectives and addressed environmental sustainability matters in its DUP. These strategic objectives referred to various issues, such as the improvement of waste management and waste minimization, the enhancement of the city's green areas, the protection of the territory from hydrogeological risk, the promotion of environmental sustainability and conservation, the reduction of air pollution, the protection and consumption of natural resources, energy sustainability and so on (see Table 1 for more details). In addition, each municipality allocates budgetary resources that are essential for sustaining the implementation of their own urban environmental sustainability objectives, and thus to ensure an effective integration of environmental policy (Wilkinson et al., 2008). However, the proportion of environmental expenditure out of the total of available budgetary resources is quite variable among the 14 metropolises, ranging from a minimum of about $4 \%$ in two cases to over $15 \%$ in some other cases. This highlights how each metropolis attributes a different saliency to environmental issues (Sandu \& Bănică, 2015).

Therefore, while some previous studies that analyzed other national urban contexts found a low level of integration of urban environmental sustainability policies in municipal planning practices (Nogueiro \& Ramos, 2014; Hermelin \& Andersson, 2018), this study's findings show extensive integration in the Italian case. A possible explanation for this result can be linked to the new budget structure that includes the specific Mission 9, which encourages the incorporation of environmental sustainability strategic objectives and supporting resources into the Italian local government budgetary system. Indeed, this new structure of missions and programs allows cities to systematically integrate and disclose sustainable urban development initiatives, thus fostering a greater sustainable development focus in local government strategic planning (Mazzara et al., 2010). Therefore, the "sustainable development and protection of the territory and the environment", which is now compatible with strategic planning discourses, appears to be an important issue for Italian metropolises. However, although the results point to a promising positive trend, they also show that efforts are still needed for an effective full integration of urban environmental sustainability into municipal budgetary strategy. As the study findings revealed, some problems persist since environmental sustainability budgetary strategy was shown to have a strong waste focus. These findings are consistent with those of Saha and Paterson (2008) who found that environmental sustainability in large US municipalities focused on specific initiatives, one of which pertained to waste. The study findings for the Italian case also corroborate the current state of the literature that looks to sustainable urban development as a persistent challenge for local government managers on a global scale (e.g., Yigitcanlar \& Teriman, 2015; Hermelin \& Andersson, 2018; Zeemering, 2018). The reduction of $\mathrm{CO}_{2}$ emissions is a major environmental sustainability challenge for cities worldwide (SDSN \& Telos, 2019). As a matter of fact, each Italian metropolitan municipality allocates most of their environmental expenditures to the budgetary program "Waste" at the expense of the other programs including "Air quality and pollution reduction", to which very scarce resources are allocated. A possible explanation for this may be that waste management and minimization represents a critical concern for Italian metropolises, where urban waste production and disposal is one of the most important environmental issues as perceived by local communities. Furthermore, as has been highlighted in the literature, an obstacle to a more effective urban environmental sustainability implementation is represented by a limited availability of financial resources which affects the related strategies (Saha \& Paterson, 2008; Vagnoni \& Moradi, 2018).

In this regard, the results for the $2 n d R Q$ showed that a strong positive linear relationship exists between the budgetary resource availability of Italian metropolises and the spending allocations for the eco-sustainable development of their urban contexts; this relationship can be expressed in an equation form as $y=35289+$ $0.0672 x$. Indeed, the study findings demonstrated that the metropolitan spending allocations for the sustainable development and protection of the territory and the environment (i.e., for budgetary Mission 9) tended to increase as the total budget revenues increased and vice versa, since they varied with a direct proportionality expressed by a 
PCC value of 0.936 . Although this strong positive correlation does not imply causation, the value of the coefficient of determination (0.877) indicated that approximately $88 \%$ of the increases in spending allocations for environmental sustainability could be explained by budget revenues. These findings enable it to be affirmed that the availability of budgetary resources causes an increase in the amount of resources invested in urban environmental sustainability and this increase is correlated to the amount of resources available. It follows that greater environmental sustainability investments are clearly influenced by greater financial resource availability. Therefore, dedicated financial incentives from central governments, from Europe or from other sources could help metropolitan municipalities and other local governments to adopt more environmental initiatives and improve sustainability integration in their budgetary strategy. Such resource incentives could prompt local government policymakers and managers to broaden their strategic focus, prioritizing and managing any one environmental concern, which is often difficult due to limited available resources.

\section{Conclusions}

The present study for the Italian case seeks to highlight the need for city governments around the world to integrate goals and resources for environmental sustainability into their budgetary strategy. The study findings discussed in the previous section have implications for policymakers, local government managers and practitioners, researchers, and all those engaged in drive for a better integration of urban environmental sustainability within governmental budgetary strategy. Sustainability in all its dimensions must become part of municipal strategic planning processes in order to foster urban sustainability in governance, performance and reporting, thus supporting local government in a transition toward the achievement of sustainable urban development (Wheeler, 2004; Davidson \& Arman, 2014; Loorbach \& Shiroyama, 2016; Niemann et al., 2016; Hossain, 2018; Zeemering, 2018). Indeed, this transition implies the integration in the budgetary strategy of goals and resources pertaining to a multiplicity of other aspects of urban sustainability such as urban safety, sustainable transport, social housing, social inclusion, suburb development, cultural heritage protection, etc. However, this study did not analyze objectives and resources relating to other budgetary missions and this can be seen as one of its main limitations. For example, transport, which also has a considerable impact on the environment, was not examined because it is included in a separate budgetary mission, one which this study did not focus on.

A wider focus in future research on the integration of strategic objectives and resources - concerning all sustainability dimensions - into the budgetary strategy of local governments could foster a full understanding of urban management in sustainable development. In addition, future studies could address the performance and impact assessment of the integration of sustainability goals into the municipal budgetary strategy. They could also analyze the related information disclosures to stakeholders in performance reporting; the promotion of urban sustainability objectives and action in the municipal budgetary strategy to promote reporting outcomes; and, more generally, the adoption of systems and tools that can help to measure and manage performance in relation to urban sustainability.

It is recommended that metropolitan municipalities integrate objectives and resources enhancing urban environmental sustainability into their budgetary strategy, by paying attention to all major environmental concerns. This is crucial in order to continue to grow, but at the same time to take care to preserve the environment and its resources. In particular, greater efforts to include air quality improvement and gas emission reduction within budgetary strategy are required. A broader commitment to strategizing urban environmental sustainability from city governments around the world is needed to ensure that cities are nicer and healthier places to live.

\section{References}

Angelo, H., \& Wachsmuth, D. (2019). Why does everyone think cities can save the planet?. In J. Hoff, Q. Gausset, \& S. Lex (Eds.), The role of non-state actors in the green transition: Building a sustainable future (pp. 193-210). Abingdon, UK: Routledge. https://doi.org/10.4324/9780429280399-11

Bebbington, J. (2007). Accounting for sustainable development performance. London: Elsevier.

Bewick, V., Cheek, L., \& Ball, J. (2003). Statistics review 7: Correlation and regression. Critical Care, 7(6), 451. https://doi.org/10.1186/cc2401

Bibri, S. E., \& Krogstie, J. (2017). Smart sustainable cities of the future: An extensive interdisciplinary literature review. Sustainable Cities and Society, 31, 183-212. https://doi.org/10.1016/j.scs.2017.02.016

Bowen, G. A. (2009). Document Analysis as a Qualitative Research Method. Qualitative Research Journal, 9(2), 27-40. https://doi.org/10.3316/QRJ0902027

Bulkeley, H., \& Betsill, M. (2005). Rethinking sustainable cities: Multilevel governance and the 'urban' politics of 
climate change. Environmental Politics, 14(1), 42-63. https://doi.org/10.1080/0964401042000310178

Burton, E., Jenks, M., \& Williams, K. (2004). The compact city: a sustainable urban form?. London: Routledge.

Campbell, S. D. (2016). The Planner's Triangle Revisited: Sustainability and the Evolution of a Planning Ideal That Can't Stand Still. Journal of the American Planning Association, 82(4), 388-397. https://doi.org/10.1080/01944363.2016.1214080

Chohan, U. W. (2019). Documentary Research: Positing Innovations in a National Budget Process. California, USA: Sage Publications. https://doi.org/10.4135/9781526469489

Davidson, K., \& Arman, M. (2014). Planning for sustainability: an assessment of recent metropolitan planning strategies and urban policy in Australia. Australian Planner, 51(4), 296-306. https://doi.org/10.1080/07293682.2013.877508

De Jong, M., Joss, S., Schraven, D., Zhan, C., \& Weijnen, M. (2015). Sustainable-smart-resilient-low carbon-ecoknowledge cities; making sense of a multitude of concepts promoting sustainable urbanization. Journal of Cleaner Production, 109, 25-38. https://doi.org/10.1016/j.jclepro.2015.02.004

Elmqvist, T., Andersson, E., Frantzeskaki, N., McPhearson, T., Olsson, P., Gaffney, O., ... Folke, C. (2019). Sustainability and resilience for transformation in the urban century. Nature Sustainability, 2(4), 267-273. https://doi.org/10.1038/s41893-019-0250-1

Figueira, I., Domingues, A. R., Caeiro, S., Painho, M., Antunes, P., Santos, R., ... Ramos, T. B. (2018). Sustainability policies and practices in public sector organisations: The case of the Portuguese Central Public Administration. Journal of Cleaner Production, 202, 616-630. https://doi.org/10.1016/j.jclepro.2018.07.244

Filho, W. L., Skanavis, C., Kounani, A., Brandli, L. L., Shiel, C., do Paço, A., ... Shula, K. (2019). The role of planning in implementing sustainable development in a higher education context. Journal of Cleaner Production, 235, 678-687. https://doi.org/10.1016/j.jclepro.2019.06.322

Finco, A., \& Nijkamp, P. (2001). Pathways to urban sustainability. Journal of Environmental Policy \& Planning, 3(4), 289-302. https://doi.org/10.1002/jepp.94

Finnegan, R. (1996). Using documents. In R. Sapsford, \& V. Jupp (Eds.), Data Collection and Analysis (pp. 138-151). London: Sage Publications.

Galera, A. N., de los Ríos Berjillos, A., Lozano, M. R., \& Valencia, P. T. (2014). Transparency of sustainability information in local governments: English-speaking and Nordic cross-country analysis. Journal of Cleaner Production, 64, 495-504. https://doi.org/10.1016/j.jclepro.2013.07.038

Gori, E., Romolini, A., \& Fissi, S. (2018). Local authorities' policies for disseminating gender equality. Evidence from Italy. Transylvanian Review of Administrative Sciences, 14(53), 38-53. https://doi.org/10.24193/tras.53E.3

Hermelin, B., \& Andersson, I. (2018). How green growth is adopted by local policy-a comparative study of ten second-rank cities in Sweden. Scottish Geographical Journal, 134(3-4), 184-202. https://doi.org/10.1080/14702541.2018.1541474

Hossain, M. M. (2018). Sustainability reporting by Australian local government authorities. Local Government Studies, 44(4), 577-600. https://doi.org/10.1080/03003930.2018.1471397

Hu, R. (2015). Sustainability and competitiveness in Australian cities. Sustainability, 7(2), 1840-1860. https://doi.org/10.3390/su7021840

Hutton, T. A. (2011). Thinking metropolis: From the 'Livable Region' to the 'Sustainable Metropolis' in Vancouver. International Planning Studies, 16(3), 237-255. https://doi.org/10.1080/13563475.2011.591144

Johnson, B., \& Turner, L. A. (2003). Data collection strategies in mixed methods research. In A. Tashakkori, \& C. Teddlie (Eds.), Handbook of mixed methods in social and behavioral research (pp. 297-319). California, USA: Sage Publications.

Joss, S. (2011). Eco-cities: The mainstreaming of urban sustainability-key characteristics and driving factors. International Journal of Sustainable Development and Planning, 6(3), 268-285. https://doi.org/10.2495/SDP-V6-N3-268-285

Keivani, R. (2010). A review of the main challenges to urban sustainability. International Journal of Urban Sustainable Development, 1(1-2), 5-16. https://doi.org/10.1080/19463131003704213

Kutner, M. H., Nachtsheim, C. J., Neter, J., \& Li, W. (2005). Applied linear statistical models (5th ed.). Boston: 
McGraw-Hill Irwin.

Loorbach, D., \& Shiroyama, H. (2016). The challenge of sustainable urban development and transforming cities. In D. Loorbach, J. M. Wittmayer, H. Shiroyama, J. Fujino, \& S. Mizuguchi (Eds.), Governance of Urban Sustainability Transitions: European and Asian Experiences (pp. 3-12). Tokyo, Japan: Springer.

Loorbach, D., Wittmayer, J. M., Shiroyama, H., Fujino, J., \& Mizuguchi, S. (2016). Governance of urban sustainability transitions: European and Asian experiences. Tokyo, Japan: Springer.

Mauro, S. G. (2019). Public Sector Performance-Based Budgeting in Italy. In M. S. de Vries, J. Nemec, \& D. Špaček (Eds.), Performance-Based Budgeting in the Public Sector (pp. 125-140). Cham, Switzerland: Palgrave Macmillan.

Mazzara, L., Sangiorgi, D., \& Siboni, B. (2010). Public strategic plans in Italian local governments: A sustainability development focus?. Public Management Review, 12(4), https://doi.org/10.1080/14719037.2010.496264

Mogalakwe, M. (2006). The use of documentary research methods in social research. African Sociological Review, $10(1), 221-230$.

Niemann, L., \& Hoppe, T. (2018). Sustainability reporting by local governments: a magic tool? Lessons on use and usefulness from European pioneers. Public Management Review, 20(1), 201-223. https://doi.org/10.1080/14719037.2017.1293149

Niemann, L., Hoppe, T., \& Coenen, F. (2016). On the benefits of using process indicators in local sustainability monitoring: Lessons from a Dutch municipal ranking (1999-2014). Environmental Policy and Governance, 27(1), 28-44. https://doi.org/10.1002/eet.1733

Nogueiro, L., \& Ramos, T. B. (2014). The integration of environmental practices and tools in the Portuguese local public administration. Journal of Cleaner Production, 76, 20-31. https://doi.org/10.1016/j.jclepro.2014.03.096

Pevcin, P. (2019). The Evolution of City Labelling in the Literature. Economics and Culture, 16(1), 40-45. https://doi.org/10.2478/jec-2019-0005

Saha, D. (2009). Empirical research on local government sustainability efforts in the USA: gaps in the current literature. Local Environment, 14(1), 17-30. https://doi.org/10.1080/13549830802522418

Saha, D., \& Paterson, R. G. (2008). Local government efforts to promote the "Three Es" of sustainable development: survey in medium to large cities in the United States. Journal of Planning Education and Research, 28(1), 21-37.

Sandu, A., \& Bănică, A. (2015). Assessing the local environmental performance in Western Moldavia (Romania). Present Environment and Sustainable Development, 9(1), 63-79. https://doi.org/10.1515/pesd-2015-0004

Schober, P., Boer, C., \& Schwarte, L. A. (2018). Correlation coefficients: appropriate use and interpretation. Anesthesia \& Analgesia, 126(5), 1763-1768. https://doi.org/10.1213/ANE.0000000000002864

Sustainable Development Solutions Network (SDSN), \& Telos, Brabant Center for Sustainable Development. (2019). The 2019 SDG Index and Dashboards Report for European cities (prototype version). Tilburg, Netherlands: Tilburg University. Retrieved from https://www.sdgindex.org/reports/sdg-index-and-dashboards-report-for-european-cities/

United Nations (UN). (2015). Transforming our world: the 2030 Agenda for Sustainable Development. New York: United Nations. Retrieved from https://sustainabledevelopment.un.org/post2015/transformingourworld/publication

United Nations (UN). (2019). The Sustainable Development Goals Report 2019. New York: United Nations. Retrieved from https://unstats.un.org/sdgs/report/2019/The-Sustainable-Development-Goals-Report-2019.pdf

Vagnoni, E., \& Moradi, A. (2018). Local government's contribution to low carbon mobility transitions. Journal of Cleaner Production, 176, 486-502. https://doi.org/10.1016/j.jclepro.2017.11.245

Wheeler, S. M. (2004). Planning for sustainability: creating livable, equitable and ecological communities. Abingdon, UK: Routledge.

Wilkinson, D., Benson, D., \& Jordan, A. (2008). Green budgeting. In A. J. Jordan, \& A. Lenschow (Eds.), Innovation in environmental policy? Integrating the environment for sustainability (pp. 70-92). Cheltenham, UK: Edward Elgar. 
Williams, B., Wilmshurst, T., \& Clift, R. (2011). Sustainability reporting by local government in Australia: Current and future prospects. Accounting Forum, 35(3), 176-186. https://doi.org/10.1016/j.accfor.2011.06.004

Williams, K. (2010). Sustainable cities: research and practice challenges. International Journal of Urban Sustainable Development, 1(1-2), 128-132. https://doi.org/10.1080/19463131003654863

Yigitcanlar, T., \& Dizdaroglu, D. (2014). Ecological approaches in planning for sustainable cities: A review of the literature. Global Journal of Environmental Science and Management, 1(2), 159-188.

Yigitcanlar, T., \& Teriman, S. (2015). Rethinking sustainable urban development: towards an integrated planning and development process. International Journal of Environmental Science and Technology, 12(1), 341-352. https://doi.org/10.1007/s13762-013-0491-x

Zeemering, E. S. (2018). Sustainability management, strategy and reform in local government. Public Management Review, 20(1), 136-153. https://doi.org/10.1080/14719037.2017.1293148

Zou, K. H., Tuncali, K., \& Silverman, S. G. (2003). Correlation and simple linear regression. Radiology, 227(3), 617-628. https://doi.org/10.1148/radiol.2273011499 